\title{
Semanario Pintoresco Español (1836-1857): Noticias sobre cultura catalana en la prensa romántica centropeninsular
}

\section{Semanario Pintoresco Español (1836-1857): Some news about Catalan culture on the romantic press of the Centre of the Iberian Peninsula}

\author{
María Victoria NaVas Sánchez-Élez (UCM) \\ mvnavas@ucm.es \\ JUAN M. RIBERA LLOPIS (UCM) \\ jumriber@ucm.es \\ Recibido: marzo de 2015. Aceptado: mayo de 2015
}

\begin{abstract}
Resumen: Vaciado del Semanario Pintoresco Español (1836-1857), publicación periódica de naturaleza miscelánea, impresa desde el centro español y peninsular, para confirmar la atención que la citada revista castellana muestra, en una dinámica ochocentista e iberista, hacia el referente cultural catalán.
\end{abstract}

Palabras clave: Relaciones culturales castellano-catalanas, protoiberismo, Semanario Pintoresco Español.

\begin{abstract}
An analysis of the Semanario Pintoresco Español (1836-1857), a periodical and miscellaneous Castilian publication, which will reveal its numerous references to Catalan culture presented from its Iberian 18th century viewpoint.
\end{abstract}

Key words: Castilian-Catalan cultural relationships, protoiberisme, Semanario Pintoresco Español.

1. Ante el ciento setenta y cinco aniversario de la aparición del Semanario Pintoresco Español (1836-1867) y con motivo del Congreso Internacional celebrado en el Museo Romántico de Madrid en $2011^{1}$, presentamos como proyecto

1 II Congreso Internacional «El Artista» y el «Semanario Pintoresco Español» en sus aniversarios (Museo Romántico de Madrid, 20-21/10/2011). Véase Arroyo Almaraz (ed.) (2012). 
llevar a cabo el vaciado de esta publicación con un determinado fin. Nuestro objetivo era ordenar sus contenidos peninsulares no castellanos, es decir, los de las otras culturas del ámbito ibérico, la portuguesa, la vasca, la gallega y la catalana. Enfocábamos el perfil pan-peninsular de la revista que entendíamos propiciado por el panorama intelectual y político que animara el crecimiento del discurso regionalista e iberista, coordenada en la cual el Semanario Pintoresco Español se nos mostraba como un hito de naturaleza protoiberista; esto último en el sentido de que inaugura las vías a favor del diálogo intercultural aunque ciertamente desde lo español como aglutinante y en una cronología inmediatamente anterior al espectro definitivamente abierto por la revolución española de 1868, el ensayismo de la Geração de 70 portuguesa y la pléyade de revistas peninsulares que avanzan hacia el cambio de siglo.

Desde entonces hemos venido haciendo sucesivas entregas, las dos iniciales sobre los correspondientes contenidos portugueses y gallegos (Navas + Ribera 2014 y 2015). A ese corpus añadimos ahora los materiales referentes a la cultura catalana, abordando bajo esta denominación la de todos aquellos territorios lingüísticamente catalanes de la antigua Corona de Aragón. Bien es cierto que este último criterio no está implícito en el planteamiento de la publicación sino que es premisa de la cual, a pesar de que pueda contradecir la consideración coetánea al respecto, entendemos como acorde con el alcance cultural del adjetivo catalán. Resta para una última entrega la noticia sobre la cultura vasca. Ocasión que esperamos aprovechar para someter a revisión la propuesta del Semanario Pintoresco Español y el lugar que nos parece que este ocupa en el desarrollo del discurso o ideología iberista.

Con el conjunto de los textos de la revista puestos a disposición de los estudiosos, pretendemos la recomposición de la polifonía cultural de la Península Ibérica, por parte de una de las mejores revistas centropeninsulares, cuyo modelo y patrón periodístico está establecido y documentado por los especialistas del periodismo español (Seoane 1983; Sánchez Aranda + Herrera 1992; Fuentes + Fernández Sebastián 1998). Sobre la base de ese entramado histórico y crítico, remitimos a las introducciones de nuestras previas aportaciones, cuyos contenidos evitamos repetir y donde ya hemos destacado aquellos componentes que convertían el Semanario en un medio idóneo desde donde vehicular la propuesta a favor de un mutuo y plural conocimiento peninsular, supuesto que hacemos por hallar en sus páginas y entre sus colaboradores; y así mismo recordamos que en tales apartados introductorios se aporta la bibliografía fundamental sobre la revista, como por ejemplo, el volumen del Dr. Simón Díaz de 1946.

2. Extraídas del Semanario Pintoresco Español un total de 177 entradas sobre materia cultural catalana, se ordenan seguidamente, teniendo en cuenta que versan sobre historia (2.1), tipología, tradiciones y leyendas (2.2), biografías (2.3), lengua y literatura (2.4), ciudades y paisajes (2.5), instituciones y monumentos (2.6), y viajes y viajeros (2.7). Advertimos, en cualquier caso, que el contenido de una de aquellas entradas puede alcanzar en ocasiones más de uno de esos puntos clasificatorios. Por dicha razón, puede aparecer repetida en la correspondiente nota de catalogación que se da a pie de cada una de las llamadas que ordenan temáticamente los apartados siguientes. En un apartado 
tercero se reúne la información acerca de los colaboradores de la revista y autores de los trabajos mencionados que, en los puntos del apartado segundo, solo han sido citados nominalmente. Asimismo, en nota a pie de página se informa brevemente sobre los personajes nombrados en el contenido de las colaboraciones. Sin embargo, ante determinados personajes que entendemos de sobra conocidos, por ejemplo, un Ramon Llull o un Lluís Vives, así como monarcas de la corona de Aragón, hemos considerado que era innecesario. En otro orden de cosas advertimos que, en lo referente a los nombres y apellidos, en los títulos y las citas de los artículos respetamos la ortografía del original mientras que en nuestro texto y en las notas a pie de página hemos actualizado la misma.

2.1 Optaremos por reordenar las entradas sobre historia en función de los territorios de la Corona de Aragón, tal y como se ha dicho, que fueran de lengua catalana - Cataluña, Valencia y Baleares - atendiendo a la cronología de los hechos informados, no a la fecha de su aparición en el SPE. No obstante esta llamada, en alguna ocasión el texto recuperado nos resitúa en la conjunción histórico-nacional de aquellos territorios. Así, firmado por V. de la F.2, identificado como Vicente de la Fuente, al tratar los episodios en torno a la fuga de Antonio Pérez del Hierro - cuando Juan de Lanuza y Perellós era Justicia de Aragón - ${ }^{3}$, debida a la detención y condena por orden de Felipe II; con tal motivo se informa de cómo se acogió a los fueros de Aragón para evitarla y se transcriben, entre otros documentos, el texto foral de 1461 que remite al conjunto de «algunas ciudades villas ó lugares del reino de Valencia, principado de Catalunya...» en función de sus «privilegios»; e interroga, por ejemplo, «ison menos extranjeros los castellanos que los valencianos y catalanes en cuya compañía peleaban nuestros padres, bajo el estandarte de las sangrientas barras?». Se parte, así pues, de la comprensión del todo histórico sobre el que posteriormente puedan abordarse las unidades que lo integran.

Acerca de Cataluña ${ }^{4}$, la rúbrica A. C. incardina el origen del condado de Barcelona en el marco de la materia carolingia, en una breve relación con

${ }^{2}$ F., V. de la (14-3-1841): «Recuerdos históricos. D. Juan de La-Nuza (Introducción)», SPE, 11, 82-85; F., V. de la (21-3-1841): «Recuerdos históricos. D. Juan de La-Nuza (Continuación)», SPE, 12, 93-95; F., V. de la (28-3-1841): «Recuerdos históricos. D. Juan de La-Nuza (Continuación)», SPE , 13, 99-100; F., V. de la (4-4-1841): «Recuerdos históricos. D. Juan de La-Nuza (Conclusión)», SPE, 14, 109-111.

3 Antonio Pérez del Hierro (1540-1611), educado en las universidades de Alcalá de Henares, Salamanca, Lovaina, Venecia y Padua, fue secretario de Cámara y secretario del Consejo de Estado de Felipe II. Juzgado por traición a la Corona y de homicidio, huyó y se exilió a Francia, muriendo en París. El artículo remite por título a Juan de Lanuza (1564-1591), Justicia de Aragón, durante el tiempo en que acontecieron esos hechos, y él mismo acabó por ser decapitado por orden de Felipe II.

4 A. C. (23-7-1854): «Origen del condado de Barcelona», SPE, 30, 233-234; Anónimo (82-1857): «Insignia de la Hacha», SPE, 6, 43-44; Anónimo (15-2-1857): «Insignia de la Hacha. Conclusión», SPE, 7, 53-55; Janer, F. (22-1-1854): «Recuerdo histórico. Sobre el parlamento de Barcelona...», SPE, 4, 26-29; Anónimo (5-10-1856): «Fiestas de la Orden del Toisón de Oro celebradas en Barcelona en el año 1519», SPE, 40, 314-316; Guillén Buzarán, J. (19-2-1843): «Estudios históricos. Levantamiento de Barcelona en el siglo XVII», SPE, 8, 60-62; Guillén Buzarán, J. (26-2-1843): «Estudios históricos. Levantamiento de Barcelona en el siglo XVII», SPE, 9, 67-69; Guillén Buzarán, J. (5-3-1843): «Estudios históricos. Levantamiento de Barcelona en el 
datos que pudieran rozar lo legendario. Mientras tanto, sin firma, se consideran dignas de difusión y acompañadas de un grabado sobre sus armas, noticias históricas extraídas de Viaje literario á las Iglesias de España de Joaquim Lorenzo Villanueva ${ }^{5}$, acerca de la tortosina Orden del Hacha, cuyo debatido origen remite a hechos del siglo XII, tras la conquista de la ciudad de Tortosa por Ramón Berenguer IV, su posterior sitio y la defensa llevada a cabo por sus valerosas mujeres; se defiende como primera fuente historiográfica de estos hechos a Francesc Martorell i Lluna ${ }^{6}$, noticia que pasaría a «los diálogos inéditos que compuso en catalán á mitad del siglo XVI D. Cristóbal Despuig, y dedicó á D. Francisco de Moncada», es decir, contenida en Los col-loquis de la insigne ciutat de Tortosa (1557). Por su parte Florenci Janer aborda la situación histórica previa al Compromiso de Caspe, que debía «dar soberano á los reinos de la Corona de Aragón en 1410», y, remitiendo a «nuestra Historia de Cataluña, inédita por no estar del todo terminada», trata del parlamento barcelonés que lo precediera, conducido desde «la provincia ó antiguo Principado de Cataluña [que] fué la que tomó la iniciativa y principal parte en tal suceso». En su artículo, el autor transcribe el documento, alaba la dirección por parte de «los gobernantes del Principado», «cabeza y centro de la monarquía», así como notifica la presencia de representantes de toda la corona y refiere la importancia de las decisiones sobre toda su geografía, incidiendo en la inestabilidad sociopolítica en que se hallaban sus otras partidas. Anónima es la colaboración sobre las fiestas barcelonesas de la Orden del Toisón de Oro en 1519, presididas por el joven príncipe Carlos I, donde, aparte de los fastos y de las autoridades participantes, se notifica su habilidad política que tanto pretendía «atraerse al propio tiempo el afecto y consideración de la nobleza de los reinos de Castilla y Aragón, distribuyendo entre sus individuos algunos collares del Toisón», como perseguía «hacerse jurar y reconocer por Conde». Juan Guillén Buzarán, en una serie de tres artículos, encabezada por el grabado del «Palacio de la Diputación Provincial y Audiencia de Barcelona» (actual sede de la Generalitat de Catalunya), relata, con un discurso y un registro casi narrativos, el levantamiento de 1638 o guerra de Els Segadors: el texto remite tanto a «Los catalanes, naturalmente feroces y poco sufridos, [que] recibieron sin estrañeza ni enojo en un principio las consecuencias de la guerra, acaso por la notoriedad del oríjen que las producía, y la necesidad imperiosa de salvar el país...», como que ante $« \ldots$ las repetidas ocasiones de los disturbios y de las ofensas, crecía con la furia y el encono de los catalanes el movimiento y agitación de Barcelona»; y avanza hacia una conclusión donde «Regocijada la turba revolucionaria con su vencimiento corrió en desorden por toda la ciudad, buscando con fiereza en los soldados castellanos nuevas víctimas que sacrificara su enco-

\footnotetext{
siglo XVII», SPE, 10, 74-76; Anónimo (9-3-1845): «Miscelánea», SPE, 10, 78-80.

5 Joaquim Lorenzo Villanueva i Astengo (1757-1837), natural de Játiva (Valencia), historiador y escritor, liberal e ilustrado. Autor de un extenso corpus sobre materia religiosa, política, oratoria, poética y autobiográfica así como de traducciones y de escritos polémicos, la obra mencionada como fuente del artículo, había comenzado a publicarse en 1803.

${ }^{6}$ Francesc Martorell i de Luna (1586-1640), historiador sobre el obispado de Tortosa (Tarragona), a propósito del cual escribió al menos dos volúmenes, Historia de la Santa Cinta... (1626) e Historia de la Antiqva Hibera... (1627).
} 
no»; mientras «Los perseguidos castellanos ahuyentados y temerosos querían huir en vano de sus feroces enemigos; reunidos en corto número eran vencidos en cuantas ocasiones intentaban pelear; y buscados en los sitios más ocultos de la población se veían arrastrados a la muerte con el furor más encarnizado». Ante toda esta información del pasado, también hallamos una anónima llamada de atención presente sobre la conveniencia de conectar ferroviariamente Barcelona con las líneas francesas y belgas, para que se «proporcionase a la industria catalana por medio de estas rápidas comunicaciones el desarrollo á que es tan acreedora».

La materia histórica de Valencia ${ }^{7}$, de la mano de Manuel Malo de Molina, nos lleva a su pasado árabe mediante la atención a la llave de la ciudad medieval que, tras aparecer en un grabado convenientemente anotado, se presenta por el autor a partir de las noticias ordenadas por Gregori Mayans, descendiente del ilustrado Gregori Mayans i Siscar ${ }^{8}$; se describe su inscripción cúfica y se añade documentación sobre dicha llave. Antonio de Trueba nos mantiene en la Valencia previa a la conquista de la Corona de Aragón al prosificar parafraseándolo el Cantar de Mio Cid, eligiendo los episodios en torno a las hijas del héroe y remitiendo inevitablemente al espacio y a la ciudad del Turia. Será Remigi Salomón quien, informando sobre el marquesado de Denia, y aun aludiendo a su pasado romano y árabe, nos acerca a los tiempos de la conquista del espacio valenciano por la casa de Aragón y a la pertenencia de este marquesado al linaje catalán de Cardonas. De la Valencia medieval, un artículo anónimo refiere la llegada y ubicación del cáliz de la última cena como reliquia a su catedral. Una serie de cuatro artículos del ya mencionado Vicente de la Fuente, trata de la expulsión de los moriscos valencianos (1609-1610), concediéndole gran importancia y acusando de parcialidad el tratamiento historiográfico concedido hasta la época. Un siglo después acontecería la batalla de Almansa (1707), notificada por S. H., como victoria que asentó en la corona española a Felipe V, «hallándose reunidos en Valencia los enemigos del rey Católico ...», y que supondría la derrota de los intereses políticos de los territorios de la antigua corona arago-

7 Anónimo (24-12-1854): «Llave de Valencia», SPE, 52, 413-414; Malo de Molina, M. (24-12-1854): «Llave árabe de Valencia», SPE, 52, 414-415; Trueba, A. de (8-1-1854): «Las fijas de Mio Cid», SPE, 2, 15-16; Trueba, A. de (15-1-1854): «Las fijas de Mio Cid», SPE, 3, 19-22; Trueba, A. de (22-1-1854): «Las fijas de Mio Cid», SPE, 4, 29-30; Salomón, R. (14-1-1855): «Noticias relativas al marquesado de Denia», SPE, 2, 11; Anónimo (25-1-1857): «Dos cálices notables de Valencia», SPE, 4, 28-30; F., V. de la (15-9-1844): «Estudios históricos. Los moriscos de Valencia», SPE, 37, 295-296; F., V. de la (22-9-1844): «Estudios históricos. Los moriscos de Valencia», SPE, 38, 298-300; F., V. de la (30-9-1844): «Estudios históricos. Los moriscos de Valencia. Alaxuar», SPE, 39, 311-312; F., V. de la (6-10-1844): «Estudios históricos. Los moriscos de Valencia», SPE, 40, 315; S. H. (1-6-1845): «Miscelánea. Batalla de Almansa...», SPE, 22, $175-$ 176; Tamarit, E. (1-11-1846): «Historia natural. Propiedades del murciélago y razones porque se halla en las armas de Valencia», SPE, 44, 350-351; Tamarit, E. (15-11-1846): «Historia natural. Propiedades del murciélago y razones porque se halla en las armas de Valencia. (Conclusión)», SPE, 46, 366-368.

8 No habiendo encontrado referencias a Gregori Mayans, a Gregori Mayans i Siscar (16991781), natural de Oliva (Valencia), cabe recordarlo al menos como jurista, historiador, lingüista y polígrafo, considerado, junto a Benito Feijóo como uno de los primeros ilustrados españoles. 
nesa. A modo de colofón, véase cómo entre la historia natural y un episodio atribuido a Jaume I, se explica la presencia heráldica del murciélago en las armas valencianas en una doble entrega de Emili Tamarit.

A propósito de las islas Baleares ${ }^{9}$, contamos con contenido arqueológico. Aparece un primer artículo que, aludiendo a la dominación fenicia, romana y morisca de Mallorca, se centra en el hallazgo y documentación histórica de un águila de bronce, desenterrada en «Pedret Bocchar, distrito de Pollenza», «pueblo romano inmediato al municipio de Pollentia». El texto de Joaquim Maria Bover va introducido por un poema de Juan Guillén Buzarán, «La águila de bronce», y despedido por unos versos de Racine que aluden a lo efímero de las glorias pasadas. El mismo estudioso notifica sobre primitivos monumentos en Mallorca, mientras que, por su parte, T. M. y R. informa sobre los correspondientes de Menorca que, en este caso y a partir de la obra de Joan Ramis i Ramis ${ }^{10}$, considera de origen celta. Tanto una colaboración como la otra van acompañadas de sendos grabados sobre construcciones piramidales.

2.2 En la línea plástica de la publicación, rica en grabados y siempre destacada por sus estudiosos, ordenamos conjuntamente las referencias que contienen representaciones de tipos e indumentarias de catalanes, valencianos y baleares ${ }^{11}$, en ocasiones acompañados de textos que describen detenidamente su vestimenta. Extraemos de ese conjunto una extensa colaboración de El Curioso Parlante, Ramón de Mesonero Romanos ${ }^{12}$, que además de los consabidos grabados cuenta con la tópica de los tipos de cada zona, reunidos narrativamente en una posada madrileña; les adjudica incluso un nombre propio y topónimo de origen, y amplía en su texto los breves perfiles aquí ya mencionados, tanto por su aspecto como por su psicología: se introduce de este modo «un valenciano ligero y frescachón, con sus zaragüelles y agujetas, manta al hombro izquierdo y pañuelo de celures a la cabeza», seguido de un catalán de «facciones ásperas», con «voz estentórea y desapacible acento gritador», vestido con «alpargatas de cáñamo y medias de estambre azul, calzón abierto de pana verde».

9 Bover, J. M. (19-2-1843): «Arqueología. Descubrimientos en Mallorca I», SPE, 8, 63-64; Bover, J. M. (27-12-1840): «Estudios arqueológicos. Las pirámides druicas [sic] de la villa de Campos en la isla de Mallorca», SPE, 52, 410-412; T. M. y R. (22-8-1847): «Antigüedades españolas. Monumentos célticos de Menorca», SPE, 34, 265-267.

10 Joan Ramis i Ramis (1746-1819), natural de Mahón (Menorca), máximo exponente del neoclasicismo en las letras catalanas. Autor de tragedias como Lucrècia (1769), escribió también en latín y regresó al castellano a partir de la reincorporación de la isla a la corona española. Celebrado también como riguroso historiador, en relación con la materia tratada en el artículo, habrá que citar Antigüedades célticas de la isla de Menorca (1818).

11 Vicente y Caravantes, J. (7-4-1839): «Usos y trages provinciales. Los valencianos (Horchatería valenciana)», SPE , 14, 109-111; Anónimo (12-7-1840): «Trages provinciales. Los catalanes», $S P E$, 28, 224; Van-Halen, F. y texto de Quadrado, J. M. (18-12-1842): «España pintoresca. Los mallorquines. Las islas Baleares», SPE, 51, 401-404; Benedicto y texto Anónimo (16-7-1843): «Mugeres del Ampurdán y montañas de Cataluña», SPE, 29, 229-230; Puig (26-11-1854): «Contrabandista del Pirineo», SPE, 48, 380.

12 El Curioso Parlante (28-7-1839): «Escenas matritenses. La Posada ó España en Madrid», $S P E, 30,233-238$. Acerca de la lectura que pueda hacerse sobre el artículo de costumbres y del alcance que quepa concederles, véase Rubio Cremades (1998). 
En este apartado nos centramos a continuación en materia estrictamente catalana ${ }^{13}$. Un grabado, integrado entre otros varios en una miscelánea, representa a un devoto delante de la «Estatua de la Virgen Ntra. Sra. de Montserrat». Tres textos, igualmente anónimos, versan por extenso, el primero sobre la capacidad económica de un barcelonés para fomentar una fortuna; el segundo sobre una colonia marsellesa de catalanes, que se tiene por real, y que parece probar que estos últimos solo ocasionalmente se relacionaron con los nativos; el tercero acerca de la producción textil y también de la maquinaria industrial de determinadas fábricas y fundiciones barcelonesas presentes en una exposición nacional, alguna de las cuales «ha dado muestras de que sus establecimientos son lo mas considerable que hay en España, y aun esceden á muchos del extranjero», pudiendo librar a los españoles de «la dependencia extranjera». Los dos primeros tienen una factura claramente narrativa. De acuerdo con M. Amores (2014: 82), que plantea que hay textos en el Semanario que aparecen anónimos o de autoridad no identificada y que cabe apreciar como traducciones, consideramos que en esa categoría cabe ordenar el primero y el segundo de esos textos. Muy puntual, por su parte, nos parece un artículo anónimo de historia natural y acerca del gato donde se arguye que si el felino está bien alimentado «puede servir también de buen alimento, y ofrecería un manjar tan agradable como la liebre, pero no es uso recibido el presentarlo en nuestras mesas, á escepcion sin embargo de las posadas de Castilla, ó de los ventorrillos de Cataluña donde todos los hemos saboreado sin escrúpulo de conciencia».

Si pasamos a temática valenciana, en primer lugar, se nos informa sobre festejos ${ }^{14}$ de raigambre popular y religiosa, dedicados a santos tradicionales de la tierra como es el caso de San Vicente Ferrer y San José — «Milacres» y «Falles»- y de San Jorge, así como a celebraciones litúrgicas como el Corpus, describiendo detalladamente la procesión y, entre sus componentes, las «alegorías y rocas», que aún hoy día conmemoran la Eucaristía, como se ve en el grabado correspondiente. Mientras que en el segundo de los textos de la nota anterior, José de Vicente y Caravantes, además de festejos, celebra la riqueza de la naturaleza valenciana, las costumbres de aires moriscos, las barracas y alquerías y «el genio jovial y bullicioso en demasía de los valencianos con los gozos de la naturaleza» - aquellos que no les parecen poco-, y que les anima a imaginar fiestas como las antes relatadas. Por su parte, el artículo que remite a las celebraciones alcoyanas en honor de San Jorge, firmado por M. Parera, nos lleva a territorio alicantino. En dicho artículo su autor menciona la lucha entre árabes y cristianos en la toma de la ciudad.

13 Anónimo (14-3-1852): Sin título, SPE, 11, 84; Anónimo (24-4-1836): «La economía de un real», SPE, 4, 34-36; Anónimo (4-11-1838): «Una colonia de catalanes», SPE, 136, 760-762; Anónimo (6-3-1842): «Industria española. Exposición de 1841», SPE, 10, 77-78; Anónimo (1-41833): «Historia natural. El gato», SPE, 1, 14-15.

14 T., R. de (1-4-1833): «Costumbres de Valencia. Les Milacres», SPE, 1, 12-14; Vicente y Caravantes, J. de (7-4-1839): «Usos y trages provinciales. Los valencianos», SPE, 14, 109-111; Anónimo (26-5-1839): «La procesión de Corpus en Valencia», SPE, 21, 167-168; Parera, M. (122-1854): «Las fiestas de San Jorge en Alcoy», SPE, 7, 50. 
Acerca de este espacio ${ }^{15}$, y tratando coincidente asunto remite, así mismo, un artículo firmado por N. B. S. donde se da cuenta más ampliamente de los festejos derivados de aquellos bélicos hechos. De manera más puntual, este último autor relata en otros dos artículos rituales villenenses, la carrera que aglutina la fiesta de Santa Ana en la romería a la ermita de Santa Lucía, y los protocolos del matrimonio. A modo de cierre de este apartado y por lo genérico de su contenido, mencionemos el texto de Baldomero Menéndez ${ }^{16}$, donde se contrastan aspectos y reacciones de un gallego y un valenciano, entendemos que sin llegar a la retórica de corte costumbrista que busca oponer tipos regionales. Somos de la opinión de que dicho texto es un relato ordenado a partir del encuentro de los dos protagonistas.

Sobre costumbres mallorquinas ${ }^{17}$, se cuenta con un artículo de Joaquim Maria Bover acerca de la fiesta de San Bernardo. En él se relata la fundación medieval del monasterio de la Real y la romería estival a dicha sede, que el autor notifica como una de las celebraciones más animadas para los palmesanos. Hay que contar, además, con la serie completa de Josep Maria Quadrado, sobre las islas, contenedora de datos sobre hábitos e ideosincrasia de sus moradores; línea en la cual habrá que añadir también un texto sobre Ibiza, firmado por El tío Fidel, identificado como Francisco Robello y Vasconi, quien, frente a la generalizada opinión de corte peyorativo sobre esta isla y sus habitantes, eleva un favorable juicio reivindicativo:

Muchas veces he tratado de averiguar el origen que pudieran tener las diatribas inventadas contra Ibiza, y jamás he podido atinar con la verdadera causa. Sin embargo, hasta hace pocos años aquel pueblo carecía enteramente de relaciones mercantiles con el continente, y aún con las otras islas: el sistema monstruoso y hasta bárbaro de prohibirles la estracción de ninguna de sus producciones, originaba, después de los muchos males consiguientes á tan atroz arbitrariedad, la de que estuviesen enteramente privados de toda clase de comunicación, esto sin duda produjo que en aquellos tiempos se formasen de Ibiza el concepto que llevo dicho y como el vulgo ni analiza las causas ni aun diferencia las épocas, ha seguido en la misma creencia que se puede llamar tradicional, cuya creencia pudiera ya haber rectificado.

2.3 En un recorrido ordenado cronológicamente, abordamos a continuación el rico conjunto de perfiles y biografías de personajes que reúne el Semanario, desde monarcas de la antigua Corona de Aragón, pasando por escritores, intelectuales y artistas del medievo, renacimiento y barroco, hasta ilustrados y románticos.

15 N. B. S. (5-5-1839): «Costumbres valencianas. Moros y cristianos», SPE, 18, 140-142; N. B. S. (21-7-1839): «Costumbres provinciales. La Carrera del Pollo», SPE, 29, 228-229; N. B. S. (25-8-1839): «Costumbres provinciales. Las bodas de Villena», SPE, 34, 270-272.

16 Menéndez, V. (12-11-1843): «Costumbres. Un valenciano y un gallego», SPE, 46, 365-368.

17 Bover, J. M. (15-6-1845): «Costumbres mallorquinas. Fiesta rural de San Bernardo», SPE, 24, 186-187; Quadrado, J. M. (18-12-1842): «Las islas Baleares», SPE, 51, 401-404; Quadrado, J. M. (25-12-1842): «Las islas Baleares», SPE, 52, 411-412; Quadrado, J. M. (1-1-1843): «Las islas Baleares», SPE, 1, 7-8; Quadrado, J. M. (8-1-1843): «Las islas Baleares», SPE, 2, 13-16; El tío Fidel (20-5-1849): «Ibiza», SPE, 20, 438-439. 
Respecto a la edad media ${ }^{18}$, del siglo XIII son el colaborador de Jaume I en las conquistas de Valencia y Mallorca, Nuch de Fullanguer ${ }^{19}$, personaje del que Julián Saiz Milanés relata los hechos épicos que le sitúan cerca del monarca; y Ramon Llull sobre quien Joaquim María Bover, tras el grabado del sepulcro del autor mallorquín, sito en el convento de San Francisco en Palma, establece biografía y corpus escogido de su obra, al tiempo que lo presenta como un adelantado a otros grandes pensadores y filósofos posteriores, y, encarándolo como «español» y «mallorquín», reclama de manera urgente y a su favor un reconocimiento y estudio por parte de la intelectualidad hispana, es decir «el servicio más distinguido que podría hacerse a la literatura española», como ya se ha hecho por parte de los académicos europeos. Atendiendo a dos monarcas emblemáticos de la Corona de Aragón, el Semanario Pintoresco Español presenta un perfil biográfico de Pere el Ceremoniós, que se cierra con una comparación con Pedro el Cruel, resultando respectivamente el primero «el Tiberio de Aragón» y el segundo «el Nerón de Castilla»; y un texto más extenso sobre Alfons V el Magnànim, tras cuyo recorrido biográfico, y, si bien no se elude la referencia a sus defectos y errores, se le retrata como «príncipe esclarecido», «hábil en las artes del gobierno», monarca de uno de los periodos de mayor gloria catalano-aragonesa, tanto en «las armas» como en «las letras», considerado «uno de los príncipes más ilustrado de su siglo», precisamente cuando «se acercaba ya el momento de su reunión con la [Corona] de Castilla para formar juntas una vasta monarquía».

Acompañados siempre por un grabado de su retrato o por una de sus obras, la nómina de figuras de la edad moderna ${ }^{20}$ va encabezada por el humanista valenciano Lluís Vives mediante dos entregas de V. de la F. de pormenorizado corte biográfico; texto donde el autor insiste tanto en su coetáneo reconocimiento continental como en el requerimiento de que España debiera incorporarlo a su catálogo de autores clásicos; se refiere asimismo su poliglotismo, campo en el que no desestimó su lengua nativa, aludiendo a que «... no hay noticia de que escribiese en lengua vulgar más que un librito sobre el arreglo de los estudios que escribió en valenciano, y [que] dirigió al ayuntamiento de su patria, y casualmente es una de las pocas obras suyas que se han perdido».

18 Saiz Milanés, J. (6-4-1856): «Nuch de Fullalguer», SPE, 14, 109-110; Bover, J. M. (6-9-1840): «Biografía española. Raimundo Lulio», SPE, 36, 285-287; Anónimo (13-12-1846): «Historia. Don Pedro el Ceremonioso», SPE, 50, 395; Anónimo (23-9-1838): «Biografía española. Don Alonso $\mathrm{V}^{\circ}{ }^{\circ}$ de Aragón», SPE, 130, 711-713.

19 Recogidas a su vez las noticias contenidas en el artículo de Julián Sáiz Milanés en el volumen de la revista Escenas contemporáneas (oct.-dic., 1959, p. 203), dirigida por Manuel Ovilo y Otero, Nuch de Fullanger es informado como maestre de Aragón, fallecido en el cerco de Valencia (1238).

${ }^{20}$ F., V. de la (3-1-1841): «Luis Vives», SPE, 1, 1-2; F., V. de la (10-1-1841): «Luis Vives», $S P E, 2$, 11-12; Anónimo (22-11-1840): «Juan de Juanes», SPE, 47, 369-370; Anónimo (11-81844): «Galería de pinturas. Escuela española», SPE, 32, 252-253; Salomón, R. (4-11-1849): «El Venerable P. Fr. Pedro Esteve», SPE, 44, 345-346; Anónimo (13-1-1856): «Un cuadro de Rivera», SPE, 2, 9-10; Anónimo (12-3-1843): «Biografía española. D. Vicente García, Rector de Vallfagona», $S P E, 11,84-86$; 
De otro valenciano, el pintor Juan de Juanes ${ }^{21}$, y en dos entregas anónimas del Semanario, la primera ordena su biografía artística, da cumplida referencia de la ubicación de sus cuadros y se le reconoce como uno de los grandes de la pintura española desde su tierra, «... de nuestra escuela, y fundador de la de Valencia», en particular por su tratamiento del color aprendido en la pintura de Rafael; y la segunda, comentando la pintura que aparece en este número - S. Esteban acusado de blasfemo ante la sinagoga - no solo se amplía la documentación biográfica sino que, del precedente comentario, se desprende que «... fue pintor filósofo, pues supo espresar las pasiones del hombre, con verdad y viveza; que conoció la belleza ideal y sublimes cualidades del arte; y que fue uno de los primeros artistas españoles, que lo demostraron en el reino». El plantel de cuna valenciana continúa con el panegírico del religioso franciscano P. Fra Esteve ${ }^{22}$, personaje piadoso tanto de raigambre popular como cortesano durante el reinado de Felipe IV, nombre detrás del cual vendrá la autoridad pictórica de Josep Rivera, el Españoleto, «una de las más esclarecidas glorias artísticas de España tan fecunda en grandes hombres». Nótese que, como ya aconteciera con Ramon Llull, los biografiados con anterioridad siempre vienen a ser resituados desde su patria de nacimiento en la órbita del espectro español, de acuerdo con el criterio de la publicación, tal y como se recordaba en el punto introductorio. Otro tanto parece acontecer con el escritor Vicent García ${ }^{23}$, Rector de Vallfagona. Cierto es que dando cumplida noticia de su origen y biografía catalana pero, sin que no dejen de tener importancia los datos y las relaciones literarias que lo centran en la Villa y Corte, se ve ensalzado desde este ámbito. Ahora bien, no es menos cierto que el artículo remite a su producción lírica en catalán y se transcribe una cuarteta suya del poema Una ninfa de Sagarra, al tiempo que se informa sobre una reedición de 1840 de su poesía y se apostilla lo siguiente: «Nos hemos abstenido de transcribir muchas de las preciosas poesías del Rector de Vallfagona, porque están escritas en catalán y solo pueden tener interés para aquellos de nuestros lectores que, conociendo el idioma, puedan apreciar sus bellezas».

Mallorquines, valencianos y dos catalanes jalonan las páginas del Semanario con su presencia ilustrada ${ }^{24}$. Se documenta el amplio abanico de especiali-

${ }^{21}$ Vicent Juan Massip (h. 1507-1579), natural de La Font de la Figuera o de la propia Valencia y conocido como Juan de Juanes. Pintor renacentista, con posible formación italiana aunque quizás aprendida merced al contacto cultural entre Nápoles y Valencia.

${ }^{22}$ Pere Esteve i Puig (1582-1658), natural de Denia (Alicante), franciscano destacado por el empleo de su lengua materna para mejor adoctrinar a sus fieles. Su persona fue motivo de dos hagiografías (Christòfer Mercader, 1677 y Leopold Ignasi Planells, 1760), que ayudaron a mantener la devoción popular hacia el fraile.

${ }^{23}$ Francesc Vicent García i Torres (1582-1623), sacerdote natural de Tortosa (Tarragona) y literariamente conocido como poeta que, en catalán, compuso lírica cercana a los modelos del barroco castellano tanto en sus sonetos como en sus sátiras.

${ }^{24}$ Bover, J. M. (24-5-1846): «Biografías españolas. Guillermo Mesquida», SPE, 21, 162-164; Ramírez y de las Casas-Deza, L. M. (19-2-1854): «Don Pedro Virgili», SPE, 8, 58-59, 61; Magán, N. (24-10-1841): «Biografía española. Don Jorge Juan», SPE, 43, 337-338; Anónimo (22-1-1854): «Don Jorge Juan», SPE, 4, 30; Bover, J. M. (20-6-1841): «Biografía española. Don Antonio Barceló», SPE, 25, 193-194; A. (22-3-1857): «Don Antonio Ponz», SPE, 12, 89-90; Tejado, G. (25-4-1847): «Biografía española. Apuntes biográficos y bibliográficos sobre el literato español D. 
zaciones que marca el setecientos. Así se nos muestran, ordenados cronológicamente el pintor de éxito continental Guillem Mesquida ${ }^{25}$ (acompañado por el grabado de su autorretrato), el cirujano Pere Virgili (grabado incluido), el científico Jorge Juan ${ }^{26}$, el marino Antoni Barceló ${ }^{27}$, el historiador y viajero Antoni Ponz $^{28}$, el polígrafo Antoni Capmany ${ }^{29}$, el humanista Juan Andrés ${ }^{30}$ y el científico Fr. Agustí Canelles ${ }^{31}$.

Por su parte, los románticos ${ }^{32}$ cierran este apartado dedicado a las biografías. El escultor Josep Piquer ${ }^{33}$ (contiene boceto de su San Gerómino), el pintor Joaquim Espalter ${ }^{34}$ (reproducción de su Santa Ana dando lección á Nuestra Señora), y el músico Vicent Cuyàs ${ }^{35}$ (acompañado de retrato del autor), nos

ANTONIO CAPMANY y sobre algunas de sus obras poco conocidas é inéditas», $S P E, 17,131$ 134; Anónimo (23-1-1853): «El abate D. Juan Andrés», SPE, 4, 25-27; Anónimo (4-10-1846): «Biografía española. El padre Canellas», SPE, 40, 319-320.

25 Guillem Mesquida i Munar (1675-1747), natural de Palma de Mallorca. Pintor barroco de formación italiana de variada temática, desde la religiosa a la mitológica, desde retratos a bodegones.

26 Jorge Juan y Santacilia (1713-1773), natural de Monforte del Cid (Alicante), científico e ingeniero naval, colaboró en la renovación de la armada española frente a los avances británicos, demostró que la tierra está achatada por los polos y a él se debe la creación del Real Observatorio de Madrid por encargo de Carlos III.

27 Antoni Barceló i Pont de la Terra (1717-1797), Capitán Toni, según apodo popular en Baleares, natural de Palma de Mallorca, marino destacado en empresas como el sitio a Gibraltar en 1779 o el ataque a Argel en 1783 contra los corsarios.

28 Antoni Ponz Piquer (1725-1792), natural de Masía de la Cerrada (Castellón), con una plural formación humanística recibida tanto en España como en Italia. Autor de Viage de España, ó Cartas en que se da noticia... (17 vols., d. 1772) y Viage fuera de España (1785), título donde defiende a su país ante las críticas esgrimidas por viajeros extranjeros.

29 Antoni de Capmany Surís i de Montpalau (1742-1813), barcelonés, polígrafo que destaca por su labor como economista y político que fuera diputado en las Cortes de Cádiz. Autor de ensayos acerca del comercio y de la actividad económica de Barcelona, que se aprecian como antecedentes de la regeneración catalana del siglo XIX.

30 Joan Andrés i Morell (1740-1817), natural de Planes (Alicante), jesuita y crítico literario ilustrado. Conocido, fundamentalmente, por sus estudios de literatura universal y comparada.

31 Agustí Canelles i Carreras (1765-1818), natural de Alpens (Barcelona), religioso y astrónomo y matemático, se le destaca por su memoria de 1816 sobre la utilidad de llevar a cabo un mapa general de Cataluña con completas observaciones sobre geografía física, historia natural, agricultura, industria y comercio, documento que de nuevo nos sitúa ante los proyectos de corte regeneracionista de inicios del ochocientos.

32 Anónimo (19-2-1843): «Galería de escultura. (S. Gerónimo-De D. José Piquer)», SPE, 8, 57-58; P. de M. (18-2-1844): «Galería de pinturas. Escuela española», SPE, 7, 49-50; Balaguer, V. (26-7-1846): «Biografía española. D. Vicente Cuyás», SPE, 30, 233-234; Carvajal, R. de (7-71850): «Don Juan Arolas», SPE, 17, 211-214.

33 Josep Piquer i Duart (1806-1871), valenciano afincado en Madrid donde ejecutó la mayor parte de su obra, llevando a cabo retratos de personajes públicos.

34 Joaquim Espalter i Rull (1809-1880), natural de Sitges (Barcelona), de formación parisina y romana, su producción se especializó en pintura histórica; académico, pintor de cámara y profesor de la Escuela Superior de Pintura, Escultura y Grabado.

35 Vicent Cuyàs i Borés (1816-1839), natural de Palma de Mallorca. Retornado a Barcelona, de donde huyera su familia a causa de la Guerra de Independencia, estudiaría música. Compuso una sinfonía y óperas como La fattuchiera (1838). 
sitúan de nuevo en la órbita de los artistas que se ubican en un medio ampliamente español, quedando al menos notificado su origen. Juan Arolas ${ }^{36}$ (grabado con retrato del autor), nos valdrá como prueba máxima del escritor nacido barcelonés y de instalación valenciana que se vuelca en una obra literaria plenamente castellana.

2.4 Encontramos en el Semanario Pintoresco Español algunas muestras de lengua catalana. Pueden aparecer testimonios orales en artículos de corte $\operatorname{costumbrista}^{37}$ : atendiendo a las tradiciones y al habla de «La clase jornalera» valenciana, Pedro Sabater incluye jaculatorias («Alabat siga Deu»), cargos de cofrades («clavariesa de Sen Vicent»), refranes («Yo me entench y balle à soles») o el estribillo de aire sentencioso al que se busca el equivalente castellano («Pastilla y bollet / Y got de quinset. Chocolate, panecillo / y vaso de á realillo»); y El Curioso Parlante, en el marco narrativo de la posada madrileña donde concurren diversos tipos regionales hispanos, presenta a un catalán que exclama en su lengua «Yra de Deu» y pasa a chapurrear un catalán macarrónico con el que intenta conectar con los interlocutores castellanos. El catalán literario $^{38}$ puede aparecer cuando se transcriben documentos de los siglos XIII y XIV; o cuando se presenta a un escritor, como es el caso ya mencionado del Rector de Vallfagona, al reproducir una cuarteta suya, de acuerdo con la llamada de (2.3), quedando reflejada la inestabilidad lingüística catalana propia de la época: «Deu la n's torn'en hora bona, / Que no falta un batxiller / Que dice que's ferá beata, / y no la hem de veurer mes».

El Semanario, sin anotación que indique que sus autores provienen de las letras catalanas ni aclarando si son traducciones, edita textos de Josefa Masanés y de Víctor Balaguer ${ }^{39}$. La publicación da noticias de la vida literaria y editorial del ámbito cultural aquí tratado: acerca de la escena valenciana que en la época moderna va creciendo en castellano mediante escritores como el bilingüe Joan de Timoneda ${ }^{40}$ y junto a él otros autores de la escuela prelopesca, de acuerdo con la aportación de Juan Colón y Colón ${ }^{41}$; coetáneamente, Víctor Balaguer —que acabará incorporándose como colaborador regular y ve repetidas veces alabada la

36 Juan Arolas (1805-1849), barcelonés, formado en Valencia y Zaragoza. Famoso poeta en lengua castellana, paradigma del personaje romántico.

37 Sabater, P. (20-20-1839): «Costumbres de Valencia», SPE, 42, 333-336; El Curioso Parlante (4-8-1839): «Escenas matritenses. La posada ó España en Madrid (1)», SPE, 31, 241-245; Anónimo (10-3-1843): «Biografía española. D. Vicente García, Rector de Vallfagona», SPE, 11, 84-86.

38 Anónimo (15-2-1857): «Insignia de la Hacha. Conclusión», SPE, 7, 53-55; Anónimo (103-1843): «Biografía española. D. Vicente García, Rector de Vallfagona», SPE, 11, 84-86.

39 Masanes, J. (10-9-1843): «Poesía. Un baile en el Ampurdan», SPE, 37, 295; Balaguer, V. (4-5-1845): «Un recuerdo sobre la tumba de doña J. R. Improvisación», SPE, 18, 140-141; Balaguer, V. (22-6-1845): «Evita, la del cuello de cisne», SPE, 25, 198-199; Balaguer, V. (27-7-1845): «En el nigrum del poeta D. Antonio de Bofarull», SPE, 30, 236.

40 Joan de Timoneda (1518/1520-1583), valenciano, poeta, dramaturgo y editor, con relevante producción tanto en catalán como en castellano. Autor bisagra entre los géneros más propios de una y otra literatura peninsular.

${ }^{41}$ Colón y Colón, J. (31-5-1840): «Literatura. Noticias del teatro español anterior a Lope de Vega», SPE, 22, 172-173. 
barcelonesa Biblioteca Dramática ó Colección de Dramas Originales por él codirigida - cuenta con el elogio de su obra Al toque de Oración! (1845) y merced a su propia crónica se informa, entre otras noticias ${ }^{42}$, sobre la actividad periodística barcelonesa de Joan Mañé i Flaquer ${ }^{43}$; aparece más noticiero periodístico de las diversas provincias catalanas y valencianas ${ }^{44}$; y se informa sobre un volumen de Bonaventura Carles Aribau ${ }^{45}$ acerca de bibliografía española ${ }^{46}$.

Anotemos para finalizar este apartado que, cuando desde el Semanario se trata el trovadorismo provenzal ${ }^{47}$, tanto se mencionan en su medio la participación de monarcas de las diferentes lenguas y reinos peninsulares, como se cita nombre y texto del trovador, de origen catalán, Guillem de Berguedà, aunque su composición aparezca traducida; y no se evita el dato acerca del influjo provenzal en la lírica catalana, ya que «... los débiles ecos de la rota lira de los provenzales penetran más allá del vecino país catalán». Sobre la conexión catalanoprovenzal se podría añadir, volviendo a detalles en este caso de orden lingüístico, que El Curioso Parlante, cuando presentaba el tipo del catalán que rescatábamos en apartado (2.2), identificaba la entonación de su personaje cabrilense como parecida al «acento provenzal» ${ }^{48}$.

2.5 Las ciudades y parajes del espacio del que nos venimos ocupando están bien representadas en esta publicación, especialmente en lo que se refiere al antiguo reino de Valencia. No obstante, empezando por Cataluña y al respecto de sus ciudades ${ }^{49}$, Barcelona se presenta relacionando su privilegiada posición geográfica y su historia - orígenes, expansión mediterránea de la Corona de Aragón de la que fuera punto neurálgico, conflictos contra el poder cen-

42 Anónimo (22-6-1845): «Miscelánea», SPE, 15, 200; L. V. (23-3-1845): «Miscelánea», SPE, 12, 96; Anónimo (30-3-1845): «Miscelánea», SPE, 13, 103-104; Anónimo (4-5-1845): «Miscelánea», SPE , 18, 135; Anónimo (1-6-1845): «Miscelánea», SPE , 22, 175-176; Balaguer, V. (3-8-1845): «Crónica de Madrid», SPE, 31, 247-248.

43 Joan Mañé i Flaquer (1823-1901), escritor y periodista de adscripción liberal, liberalismo que moderaría pero manteniendo siempre su independencia de criterio. Director del Diari de Barcelona (1865-1901), como periodista se había iniciado como crítico teatral, actividad que pudiera haber acentuado su relación con Víctor Balaguer.

${ }^{44}$ L. V. (23-3-1845): «Miscelánea», SPE, 12, 96; Anónimo (12-7-1846): «Crónica», SPE , 28, 224; Anónimo (31-12-1848): «Periódicos de las provincias», SPE, 53, 428.

45 Bonaventura Carles Aribau i Farriols (1798-1862), barcelonés, intelectual integrado en la vida política y cultural española, es, por antonomasia, uno de los introductores del romanticismo desde las páginas de El Europeo (1823) y, a su vez, autor del poema La Pàtria. Cobles (El Vapor, 1833), umbral de la Renaixença.

46 Anónimo (20-9-1846): «Crítica literaria», SPE , 38, 302-303; Anónimo (28-2-1847): «Crónica», SPE, 9, 72.

47 Anónimo (15-5-1836): «Un trovador», SPE, 7, 58-60; Aquino, A. de (10-6-1855): «El amor como elemento de arte, considerado en la poesía lírico-erótica de los provenzales», SPE, $23,179-181$.

${ }^{48}$ El Curioso Parlante (28-7-1839): «Escenas matritenses. La posada ó España en Madrid», SPE, 30, 233-238.

49 Anónimo (26-3-1837): «Barcelona», SPE, 52, 97-99; Anónimo (22-4-1838): «Vista de Barcelona», SPE , 108, 542; Anónimo (14-11-1852): «Vista de la Junquera», SPE, 46, 361; Anónimo (14-8-1853): «Paseo por España. Lérida», SPE, 33, 258-260. 
tral_-; asimismo se documenta su arquitectura y principales monumentos, su tradición artística y letrada así como industrial, y también se dibuja el perfil de sus naturales «independientes y altivos por carácter, dispuestos á la rebelión y a la lucha, se hallaron muchas veces en guerra abierta con sus propios soberanos y contra la corona de España». El Semanario incluye dos grabados con panorámicas de la urbe, cerrándose el texto que encabeza la primera de esas imágenes y tras el panegírico antes resumido, con la siguiente consideración:

... sin embargo, forzoso es pensar que todas estas ventajas de Barcelona, no son tan pronto accesibles á un forastero, pues el espíritu de provincialismo, la diferencia del lenguaje mas y comun, cierta aspereza de modales y una mediana desconfianza con los recien venidos, establecen entre ellos y los habitantes de la ciudad, una barrera que solo el tiempo, el ingenio y un proceder recto son capaces de destruir; pero una vez llegado este caso, el forastero puede estar seguro de entrar de lleno en los goces que le brinda una de las ciudades más civilizadas de Europa.

Otros dos textos nos sitúan en la Junquera — acompañada de un grabado, la población se presenta como núcleo «...tan laborioso como cualquiera de los centros industriales, [que] no conoce la miseria ni la perjudicial disipación de las ciudades»- y en Lérida. A propósito de esta segunda capital de provincia, se menciona su situación geográfica, sus monumentos, su población, su limitada industria, al tiempo que se critica «su falta de moral y de civilización»; negativo perfil que se compensa mediante un glorioso recorrido por la historia de la ciudad desde las fuentes y episodios de la antigüedad clásica hasta el medievo, su participación «en la guerra insurreccional encendida en España á mediados del siglo XVII», así como en la lucha contra la invasión francesa.

Los parajes de Cataluña visitados por la publicación ${ }^{50}$, casi siempre acompañados por grabados y en alguna ocasión únicamente la ilustración, se ofrecen, en su caso, dando datos de orden geográfico, histórico, arquitectónico y, en la entrada sobre Cervià (Lérida), de corte memorial que animan a su visita por lo cual los textos incluidos se pudieran tener en cuenta como propuestas viajeras, acordes con lo que se ordenará en el apartado (2.7). No es ocasional que se insista en los parajes recuperados como signo de la identidad catalana. Por ejemplo, de Montserrat se apostilla que

Es la perla de Cataluña, según discretamente la llama el padre Argaiz, el emblema del antiguo principado, y el iman de la arraigada devoción de los catalanes. La portentosa imágen de Nuestra Señora, llamada antes la Morena, y hoy dia la Virgen de Monserrate, que se adora en su devoto santuario, uno de los de mayor

50 Anónimo (12-2-1837): «Monserrat», SPE, 46, 49-50; Anónimo (28-11-1841): «España pintoresca. Montaña de Salt de Cardona», SPE, 48, 377-378; Anónimo (29-5-1842): «España pintoresca. Vista de Manresa», $S P E, 22,169$; Anónimo (2-1-1848): «El puente de Ceret», SPE, 1, 3; Macia, L. (17-11-1850): «Las salinas de Cardona», SPE, 46, 361; Anónimo (16-2-1851): «San Juan de Villatorrada», $S P E$, 7, 56; Viladot y Sanuy, A. (26-9-1852): «Las ruinas de las Bessas y el pueblo de Cerviá», SPE, 39, 305-309; Fustagnera y Fuster, J. (11-9-1853): «Monserrate», SPE, 37, 289-291; Anónimo (26-11-1854): «La roca de Castel-Follit de Cataluña», SPE, 48, 377. 
veneración de todo el orbe católico ha sido visitado en todas épocas por reyes, prelados y un inmenso número de personas piadosas de todas jerarquías, clases y condiciones, quienes han encontrado en su visita al sagrado monte toda la suma de consuelos y dulces satisfacciones que en su viaje se propusieron.

De las ciudades valencianas ${ }^{51}$, y empezando por su capital, el texto al que acompaña un grabado, y que de alguna manera reitera los lugares comunes arriba citados a propósito de Barcelona, se inicia con una mención a la impronta árabe de la urbe levantina que pensamos que, en algún modo, se proyecta sobre lo que seguidamente se puntualiza acerca del trazado, adornos y nombres del callejero, del bullicio de sus calles, de su huerta y del sistema de riego, de las instalaciones de los baños urbanos... Tal vez, a esos gustos se podría sumar el de la floricultura que advierte otro texto. Junto a todo ello, en todo caso, no se deja de aludir a la imagen establecida por los románticos europeos como ciudad de templos y campanarios - silueta en la que insiste un grabado independiente con la urbe asomada a las orillas del Turia-, a su actividad industrial y a su tradición científica y artística. Pero ese perfil de la capital, como en el caso del artículo dedicado a las gentes de Barcelona, se contrarresta con su colofón:

Una ciudad tan civilizada y que reúne tantos encantos, un pueblo cuya actividad y la riqueza de su suelo produce á todas las clases medios suficientes para satisfacer sus necesidades, un clima blando y apacible que favorece la dulzura del carácter provincial, presenta sin embargo un contraste marcado en el crecido número de desgracias que suelen originarse del robo y las venganzas particulares, y que hacen peligrosas sus calles, especialmente de noche. Sin embargo el cuidado de las autoridades ha disminuido en parte este peligro, estableciendo un alumbrado regular y una compañía de serenos ó vigilantes, institución importantísima de que dio el ejemplo esta ciudad, y que después fue seguido por las principales del reino.

Otras localidades perfiladas geográfica, histórica y plásticamente en el Semanario son Morella, Denia, Elche y Alicante; a propósito de esta última se puntualiza lo siguiente:

Alicante cuya importancia ha aumentado desde que en 1833 dejó de ser partido
de la provincia de Valencia, está llamada a ser una de las provincias de España,
si como es de esperar llega un día en que se realice el proyecto de facilitar su
comunicación con Madrid, en términos de que puedan atravesarse las 72 leguas
que separan entrambas poblaciones en siete horas y media; lisonjero es el por-
venir que le aguarda, y completo el cambio favorable que va á a esperimentar.

51 M. (21-8-1836): «Valencia», SPE, 21, 169-171; Anónimo (14-5-1848): «Vista de Valencia», SPE, 20, 160; Anónimo (28-6-1840): «Floricultura», SPE, 26, 207; Guillén Buzarán, J. (12-7-1840): «España pintoresca. Morella», SPE, 28, 217-218; Salomón, R. (7-5-1848): «La ciudad de Denia», SPE, 19, 145-147; Salomón, R. (14-1-1855): «Noticias relativas al marquesado de Denia», SPE, 2, 11; Anónimo (20-3-1842): «España pintoresca. Elche y sus palmares», $S P E, 12,95-96$; R. (5-7-1846): «España pintoresca. Alicante», SPE, 27, 209-210; Pastor de la Roca, J. (22-4-1855): «Alicante artístico y monumental», SPE, 16, 121-122. 
Respecto de los parajes valencianos ${ }^{52}$ se mencionan e ilustran además de La Albufera, valorada tanto paisajística y cinegéticamente como canal de comunicación y merecedora de un poema firmado por M. M. F., el alicantino pantano de Tibi, la segorbina cueva-ermita de Llanderó, las ruinas de Sagunto, las dianenses cuevas de Benidoleig y de Andreuet, descritas por Remigi Salomón, en las laderas del Montgó.

De la serie de cuatro artículos firmada por Josep Maria Quadrado dedicada a las Baleares ${ }^{53}$ —apartado (2.2), notas 11 y 17 donde destacábamos la ilustración de tipos mallorquines que la encabeza, junto al resto de su contenido-, hay que rescatar en este bloque lo referente a sus ciudades - Palma, Ciudadela, Mahón y otras villas de cada una de las islas-. Insisten los textos en su entorno geográfico, en su historia, en su población y en la riqueza agrícola de las mismas, abarcando más asuntos e incorporando tanto noticias sobre sus naturales como referencias a concretos parajes isleños. El autor atrae nuestra atención hacia el entorno idílico de, por ejemplo, Palma:

Los palmesanos aman el campo apasionadamente, y á fé que tienen razón en amarle, pues paisage mas ameno y variado que el que rodea sus muros, que el que pueden descubrir desde sus azoteas, difícilmente se encuentran. En los alrededores, cuajados de quintas y caseríos, apenas hay familia de la ciudad que no tenga un techo donde guarecerse de los ardores del verano, ó donde gozar del hermoso sol del invierno; y las más distinguidas y pudientes pasan á veces la mitad del año en sus quintas esparcidas por toda la isla, y adornadas á menudo con más gusto y esmero que sus casas de la ciudad.

Añádase puntualmente que sobre la ciudad de Palma cabe aludir tanto al grabado que ofrece una vista de su recinto aun amurallado como al inicio del texto que Joaquim Maria Bover dedicará a la catedral palmesana.

2.6 El Semanario Pintoresco Español reúne un conjunto de estudios tanto sobre monumentos prehistóricos (ya mencionados en 2.1) ${ }^{54}$ como, más ampliamente, clásicos ${ }^{55}$, en consonancia con la colonización de los territorios que aquí

52 Anónimo (25-11-1838): «España pintoresca. La Albufera de Valencia», SPE, 139, 783-784; M. M. F. (19-7-1846): «Poesía. La Albufera», SPE, 29, 231; Anónimo (21-4-1844): «España pintoresca. El pantano de Tibi», SPE, 16, 121-122; Anónimo (22-11-1846): «España pintoresca. La cueva santa de Valencia», SPE, 47, 569-571; Anónimo (13-2-1848): «Fragmento de las ruinas de Sagunto», SPE, 7, 56; Salomón, R. (4-11-1849): «La cueva de Benidoleig», SPE, 44, 347; Salomón, R. (29-12-1850): «La cueva de Andreut», SPE, 53, 409.

${ }_{53}$ Quadrado, J. M. (18-12-1842): «Las islas Baleares», SPE, 51, 401-404; Quadrado, J. M. (25-12-1842): «Las islas Baleares», SPE, 52, 411-412; Quadrado, J. M. (1-1-1843): «Las islas Baleares», SPE, 1, 7-8; Quadrado, J. M. (8-1-1843): «Las islas Baleares», SPE, 2, 13-16; Bover, J. M. (2-5-1841): «España pintoresca. La seu de Palma (Vista de la ciudad de Palma)», SPE, 18, 144.

${ }^{54}$ Bover, J. M. (27-12-1840): «Estudios arqueológicos. Las pirámides druicas [sic] de la villa de Campos en la isla de Mallorca», SPE, 52, 410-412; T. M y R. (22-8-1847): «Antigüedades españolas. Monumentos célticos de Menorca», SPE, 34, 265-267.

55 Anónimo (27-11-1836): «El acueducto de Tarragona», SPE, 35, 281-282; Anónimo (6-51838): «Arco romano de Cabanes», SPE, 110, 554-555; Anónimo (16-9-1838): «Antigüedades 
venimos abordando. De origen fundamentalmente romano, restos arquitectónicos civiles y religiosos, inscripciones, escultura y muestras de numismática y de arte funerario, provenientes de toda esa geografía son detalladamente descritos, documentados históricamente y siempre ilustrados.

En correspondencia con la identidad histórica y el periodo de mayor esplendor de la Corona de Aragón, junto quizás con el gusto acorde por parte de una publicación y redacción que cabe entender como romántica, el número de artículos dedicado a monumentos medievales es mucho mayor. De nuevo remitiendo en nota a pie de página a los ubicados en Cataluña ${ }^{56}$, Valencia ${ }^{57}$ y Mallorca $^{58}$,

romanas de Costúr», SPE, 129, 708-709; Anónimo (14-2-1841): «Antigüedades españolas. El arco de Bara», SPE , 7, 53-54; Cortina, I. de la (23-8-1846): «Antigüedades españolas. Sileno encontrado en Tarragona», SPE, 34, 265-266; Salomón, R. (17-9-1848): «El templo de Diana en la ciudad de Denia», SPE, 38, 297-298; Pastor de la Roca, J. (25-2-1855): «Monumentos de Sagunto. Teatro», SPE , 8, 63-64; Anónimo (2-11-1856): «Restos del teatro de Sagunto», SPE, 44, 348-349; Anónimo (9-11-1856): «Restos del teatro de Sagunto», SPE, 45, 354-355; Anónimo (16-11-1856): «Restos del teatro de Sagunto», SPE, 46, 361-363; Anónimo (1-3-1857): «Célebre sepulcro romano, que se conserva y sirve de pila bautismal en la Colegiata de San Pedro de Ager», SPE, 9, 68-69.

56 Anónimo (4-12-1836): «Baños árabes de Gerona», SPE, 36, 289-291; Anónimo (11-12-1836): «Sepulcro de los reyes de Aragón», SPE, 37, 297-299; Anónimo (6-2-1842): «Puerta antigua de Barcelona», SPE, 5, 46; Anónimo (22-5-1842): «España pintoresca. La catedral de Tarragona», SPE, 21, 161-162; Anónimo (10-7-1842): «La casa de la Diputación (hoy Audiencia de Barcelona) y Archivo General de la Corona de Aragón», SPE, 28, 217-218; Anónimo (2-6-1844): «España artística. La catedral de Gerona», SPE, 22, 169-171; F., V. de la (11-8-1844): «España artística. Claustro de S. Cugat del Vallés», SPE, 32, 249-251; Anónimo (9-4-1848): «La catedral de Barcelona», SPE, 15, 113-115; Anónimo (23-4-1848): «La catedral de Barcelona. Conclusión», SPE 17, 129-130; Anónimo (25-8-1850): «Castillo de Orís (Cataluña)», SPE, 34, 272; Fustagnera y Fuster, J. (26-10-1851): «San Pablo del Campo. Antiquísimo monasterio de monges benedictinos de Barcelona», SPE, 43, 338-339; Fustagnera y Fuster, J. (2-11-1851): «San Pablo del Campo. Antiquísimo monasterio de monges benedictinos de Barcelona», SPE, 44, 348-349; Anónimo (13-2-1853): «Escalera del púlpito de la catedral de Barcelona», SPE, 7, 49; Anónimo (27-11-1853): «Sillón del coro de la catedral de Barcelona», SPE, 48, 380; Anónimo (27-11-1853): «Sillón del coro de la catedral de Barcelona», SPE, 48, 381.

57 Anónimo (20-11-1836): «La lonja de Valencia», SPE, 34, 273-274; Anónimo (16-9-1838): «España pintoresca. La catedral de Valencia», SPE, 129, 703-704; Anónimo (9-12-1838): «España pintoresca. La puerta de Serranos de Valencia», SPE, 140, 806; Tamarit, E. (13-12-1846): «España pintoresca. La catedral de Valencia (I)», SPE, 50, 393-395; Salomón, R. (7-5-1854): «Antiquísimo monasterio de San Martín», SPE, 19, 145-146; Anónimo (30-6-1855): «Convento de San Ginés, en el campo de Salinas, provincia de Alicante», SPE, 26, 201; Albaceto, J. (22-7-1855): «Castillo de Tiar en el campo de Salinas, después convento, y hoy casa ruinosa en la dehesa de Campo Amor», SPE, 29, 225-226; Anónimo (3-2-1856): «Puerta del Cuarte en Valencia», SPE, 5, 33; Anónimo (6-4-1856): «Puerta de Serranos en Valencia», SPE, 14, 105.

58 Anónimo (14-6-1840): «España pintoresca. La lonja de Palma», SPE, 24, 185-186; Bover, J. M. (15-11-1840): «España pintoresca. El castillo de Bellver», SPE, 46, 361-362; Bover, J. M. (2-5-1841): «España pintoresca. La Seu de Palma», SPE, 18, 144; Bover, J. M. (9-5-1841): «España pintoresca. La Seu de Palma», SPE, 19, 145-146; Bover, J. M. (10-12-1843): «Antigüedades españolas. Convento de Santo Domingo de Palma», SPE, 50, 393-394; Bover, J. M. (1-9-1844): «Antigüedades. El arco de la Almudaina», SPE, 35, 277-278; Bover, J. M. (4-5-1845): «El sepulcro del obispo Torrella. En la catedral de Palma», SPE, 18, 137-138; Anónimo (5-10-1851): «La torre del Ángel en Palma», SPE, 40, 317. 
nos limitaremos a indicar que van prolijamente presentados histórica y también artísticamente e ilustrados de cuidadoso modo.

Se ordenan, asimismo, instituciones religiosas y civiles de los tres territorios, acogidas en edificaciones que, aun teniendo cimientos medievales, su construcción se acabó o remodeló a posteriori ${ }^{59}$. Además, se inventarian sedes y elementos artísticos ulteriores que, del renacimiento al siglo diecinueve, nos sitúan ya en el ámbito de la Corona de España ${ }^{60}$. No obstante, el mayor protagonismo concedido por la revista al pasado medieval incluido en este apartado, quizás puede verse condensado cuando en un par de artículos se ensalza el Archivo Real y General de la Corona de Aragón y se presenta el napolitano Arco Triunfal levantado en honor de Alfons $\mathrm{V}^{61}$. Y, como sobre arquitectura histórica se ha tratado, parece oportuno incluir la serie de artículos de Josep Maria Quadrado acerca del mantenimiento y conservación de los edificios históricos ${ }^{62}$.

2.7 La argucia de ordenar el texto en torno a unos hipotéticos viaje y viajero aparece en artículos ya reseñados, que nos describían parajes, ciudades o monumentos. Además de estos, no es mucha la cantidad de entradas explícitas sobre la actividad viajera en este Semanario $^{63}$. Solo hemos rescatado el resultado de un viaje de estudio a Mallorca y que acabó con la recuperación de un mapa coincidente con el Atles Català del judío Cresques Abraham de 1375; la relación de una visita palmesana de un anónimo viajero por entre la alameda ocupada por multicolor gentío, el muelle y la despedida de la bahía desde el mar; así mismo, la encomiástica narración de Agustín Bonnat acerca de las mujeres y de la atmósfera de la alicantina Jijona; casi una propuesta de turismo termal si leemos el artículo de Manuel Arnús sobre el establecimiento de aguas minerales de Puda, junto a Montserrat; y el viaje biográfico del ilustrado castellonense Antoni Ponz, ya citado, y autor asimismo de Viaje de España, ó cartas en que se da noticia de las cosas más apreciables y dignas que hay en ella.

59 Anónimo (19-2-1837): «Monasterio de N. ${ }^{a}$ S. ${ }^{\text {a }}$ de Monserrat», SPE, 47, 57; Anónimo (22-10-1843): «España pintoresca. Casas Consistoriales de Palma», SPE, 45, 337-338; Anónimo (4-2-1844): «España pintoresca. La Lonja de Barcelona», SPE, 5, 33-35; Bover, J. M. (4-10-1840): «La cartuja de Valldemusa», SPE, 40, 319-320.

60 Anónimo (25-2-1844): «España artística. El Altar mayor en la Iglesia Colegiata de Játiva», SPE, 8, 57-59; Salomón, R. (23-2-1851): «El exconvento de Jesús Pobre», SPE, 8, 57; Pastor de la Roca, J. (4-5-1856): «Colegio de Corpus Christi ó del Patriarca en Valencia», SPE, 18, 142-143; Bravo, E. (9-3-1851): «Gran Teatro del Liceo en Barcelona», SPE, 10, 73-74.

${ }^{61}$ V. C. (11-11-1838): «Arco Triunfal en honor de Alonso V. ${ }^{\circ}$ de Aragón en el Castel Nuovo de Nápoles», SPE, 137, 767-768; Anónimo (14-3-1852): «Archivo Real y General de la Corona de Aragón», SPE, 11, 81-82.

${ }_{62}$ Quadrado, J. M. (23-11-1851): «Del vandalismo en arquitectura», SPE, 47, 375-376; Quadrado, J. M. (30-11-1851): «Del vandalismo en arquitectura», SPE, 48, 378-379; Quadrado, J. M. (7-12-1851): «Del vandalismo en arquitectura», SPE, 49, 385-387.

63 Anónimo (4-2-1838): «Mapa antiguo», SPE, 97, 452; Anónimo (15-4-1838): «Viages. Una noche en Palma», SPE, 107, 531-532; Bonnat, A. (7-9-1856): «Recuerdos de un viaje. Al señor D. Miguel de Lucas», SPE, 36, 282-283; Arnús, M. (26-8-1855): «Baños de la Puda. Establecimiento de aguas minerales sulfurosas», SPE, 34, 265-267; A. (22-3-1857): «D. Antonio Ponz», SPE, $12,89-90$. 
3. En este punto hacemos mención a las firmas de los colaboradores que participaron con artículos de contenido catalán, entendido este término como denominador común que abarca, como dijimos al inicio, los territorios de la Corona de Aragón de lengua catalana. De entrada destacamos por ser el fundador y director de la publicación a Ramón Mesonero Romano, El Curioso Parlante, que con dos entradas firma como tal un par de textos donde, de acuerdo con su literatura costumbrista, presenta tipos catalanes y valencianos. Encabezados ambos con el título «Escenas matritenses. La Posada ó España en Madrid» y fechados en 1839, estas aportaciones han de considerarse germen de su posterior colaboración en los volúmenes de Los españoles pintados por sí mismos (1843-1844), bajo el encabezamiento de «La patrona de huéspedes». Según Hernández Sánchez (2012: 13) la inicial M. se corresponde con este mismo autor, de acuerdo con lo cual habría que añadir a la nómina anterior la entrada sobre la ciudad de Valencia ordenada en el apartado (2.5).

Respecto al conjunto de colaboradores, destaca el mallorquín Joaquim Maria Bover i de Roselló (1810-1865), historiador que alcanzó el cargo de cronista general de Mallorca en 1856, investigó ampliamente sobre la historia balear, reuniendo sus materiales en volúmenes manuscritos titulados Miscelánea erudita majoricense, fuente de sus futuras publicaciones desde los años treinta y de donde cabe suponer que se desglosan los contenidos aquí recogidos en un total de once artículos; en correspondencia con los primeros pasos de la regeneración catalana literaria, editó Del origen, vicisitudes y estado actual de la literatura en la isla Mallorca (1839) y Biblioteca de escritores baleares (1868) y, así mismo, se conservan poesías inéditas en catalán y material para un Diccionario manual mallorquín-castellano. Con ocho entradas, Remigi Salomón (s.f.), natural y juez de Denia y magistrado de la Audiencia de Granada, se interesó por la historia antigua de su ciudad, destacando por la recuperación de restos arqueológicos. El menorquín Josep Maria Quadrado (1819-1896), historiador, archivero, periodista y poeta, la materia de los siete trabajos publicados en el Semanario estarían en consonancia con el contenido que ordenó en su volumen Islas Baleares (1888); en cuanto a su aportación al proceso regeneracionista catalán desde Baleares, cabe señalar su participación en La Palma del Museo Balear (1840-1841), órgano difusor del romanticismo conservador y los estudios sobre clásicos medievales incorporados a Historia de la conquista de Mallorca (1850), así como la edición de obras de Ausiàs March y de Ramon Llull. Del barcelonés Víctor Balaguer i Cirera (1824-1901), dramaturgo, poeta, periodista, historiador y político, sus textos en el Semanario remiten a buena parte de esas variadas actividades; señalaremos que, habiendo polemizado con Antoni de Bofarull ${ }^{64}$ en los medios regeneracionistas catalanes y habiendo contestado a la obra de tono tradicionalista de Bofarull, Los trobadors nous (1858), con su progresista Los trobadors moderns (1859), el tono de enfrentamiento entre ellos podría detectarse todavía en la poe-

${ }^{64}$ Antoni de Bofarull i de Brocà (1821-1892), habiéndose iniciado en estudios de Derecho e incorporado a la Renaixença, colaboró desde diversos frentes institucionalmente, animando la convocatoria de los Jocs Florals, como archivero desde su labor en el Arxiu de la Corona d'Aragó, y como escritor y fundamentalmente con la obra La orfeneta de Menargues o la Catalunya agonisant (1862), texto apreciado cronológicamente como primera novela de la restauración literaria catalana. 
sía «En el nigrum del poeta don Antonio de Bofarull», contenida en el Semanario (2.4, n. 40). Por su parte, Juan Guillén Buzarán (1819-1892), murciano de origen, militar, historiador y poeta, en su participación en esta revista, acerca del setencentista levantamiento acaecido en Barcelona, conjuga sus dos primeras actividades. Del barcelonés Jaume Fustagnera y Fuster, de quien no hemos podido localizar más datos, contamos con tres colaboraciones que, por su contenido histórico-artístico han merecido ser catalogadas en Bibliografía del Arte en Espa$\tilde{n} a$. Artículos de revistas ordenados por autores (1978). Sobre Emili de Tamarit (m. 1882), posiblemente de origen valenciano y por lo que sus artículos versarían sobre materia levantina, a su actividad como docente y comisario militar está vinculada su producción historiográfica sobre el 2 de mayo y lexicológica sobre vocabulario técnico castrense. Del vizcaíno Antonio María de Trueba y de la Quintana (1819-1889), autor de extensa obra en verso y en prosa, su aportación en tres entregas en el Semanario viene de la mano de materia relacionada con el cantar de gesta y Mio Cid, que ha de ser punto de partida de su posterior novela histórica Las hijas del Cid (1859). También son tres las entregas del alicantino Josep Pastor de la Roca (1824-1875) cuando recoge asuntos relativos a Sagunto, Alicante y Valencia, contenido histórico levantino sobre el que también abundaría en El museo universal (1857-1869).

Una única aportación tienen los autores de la siguiente relación que iniciamos alfabéticamente con el madrileño Antonio de Aquino e Izardo (1829-1906), profesor de literatura en el Instituto de Toledo, quien abunda en su dedicación profesional en la colaboración incluida en el Semanario; el autor cuenta con un pormenorizado perfil biográfico (Prieto Prieto 2014). El leridano Manuel Arnús de Ferrer (1813-1878), médico con extensa obra publicada sobre hidroterapia y balnearios, que él mismo hizo fundar como el de Panticosa, es autor de la memoria La Puda, establecimiento de aguas minerales sulfurosas situado en la margen izquierda del río Llobregat, en el término de Esparraguera, en la provincia de Barcelona (1853), que resumiría en el Semanario. El madrileño Agustín Bonnat (1831-1858), jurista con buena formación en arte y literatura, tiene una amplia y variada colaboración temática en el Semanario, donde cabe la evocación viajera del autor aquí ordenada que parece coincidir con el contenido de otras de aquellas entradas a diferentes destinos. Sobre Juan Colón y Colón (s.f.), de reconocido prestigio como crítico del Siglo de Oro, materia sobre la que informa desde las páginas del Semanario, en contrapartida no hemos localizado biográficamente otros datos. De Vilanova i la Geltrú, Ivo de la Cortina y Roperto (1805-post.1876), aunque sin formación académica llegó a ser un reconocido arqueólogo (Canto 2001). El barcelonés Florenci Janer i Graells (18311887), formado en derecho, historiador, archivero y editor de textos antiguos castellanos y catalanes, al abordar en su artículo del Semanario el vacío dinástico de la Corona de Aragón al inicio del siglo XV, estaría informando sobre el ensayo que publicaría un año después Examen de los sucesos y circunstancias que motivaron el Compromiso de Caspe (1855). Solo datado gracias a su etapa como estudiante en Toledo en la década de 1830 y como colaborador en la prensa romántica madrileña a partir de 1840, está Nicolás Vicente Magán, en cuya producción periodística destaca el biografismo, materia con la que coincide en el texto previamente aquí ordenado. El granadino Manuel Malo de Moli- 
na y Hurtado (1818-1864), abogado, historiador y arabista, tratando acerca de elementos árabes en la historia de Valencia en un artículo de 1854, podría estar informando sobre la recopilación de materiales que aparecerían en su posterior El Cid. Rodrigo el Campeador: Estudio histórico fundado en las noticias que sobre este héroe facilitan las crónicas y memorias árabes (1857), ensayo que le llevó a la Real Academia de la Historia. La tarraconense Maria Josepa Massanés i Dalmau (1811-1887), poeta que transitó desde la lengua castellana a la catalana, sería incluida en la antología ya mencionada, Los trobadors nous de Víctor Balaguer; personaje influyente este último en la publicación, debió ser el intermediario para la inclusión de su poema; no obstante apréciese que el Semanario, una de las publicaciones pioneras en su promoción, atendió a la presencia de las románticas españolas (Burguera 2011; Lledó Patiño 2012). El asturiano Baldomero Menéndez Pintado (h.1823-1875/1876), tío de Marcelino Menéndez y Pelayo, poeta y periodista de tendencia humorística, cumple con este perfil al componer su encuentro entre un valenciano y un gallego. El cordobés Luis María Ramírez y de las Casas Deza (1802-1874) fue médico, dedicado a la investigación histórica, que convirtió en su verdadera profesión; centrado en la historia de su ciudad, en su colaboración en el Semanario atendió a su formación médica al biografiar al cirujano Pere Virgili ${ }^{65}$. La firma de Pedro Sabater, a pesar de la materia tratada en la colaboración reseñada, puede identificarse con la de Pedro Sabater y Novergué (m. 1846), figura política madrileña y marido de Gertudris Gómez de Avellaneda, pues suyas son también colaboraciones poéticas de corte romántico legendario aparecidas en el Semanario. El pacense Gavino Tejado Rodríguez (1819-1891), escritor poligenético, periodista y traductor, al parecer la reseña de corte biobibliográfico solo la practicó en el caso que nos queda notificado. Del procesalista zaragozano José de Vicente y Caravantes (h. 1820-1880), de reconocido prestigio por figuras como Niceto Alcalá-Zamora y ámbitos como el hispanoamericano, no hemos encontrado referencia en su bibliografía a títulos que no sean de orden jurídico y que conecten con el asunto tratado en esta revista. El leridano Antoni Viladot i Sanuy (1815-1878), farmacéutico y humanista, de filiación política carlista; su colaboración sobre la fundación de Cervià a partir del despoblamiento de Les Besses en un texto a caballo de lo histórico y lo descriptivo, pudiera conectar con su faceta ilustrada a la que aluden las breves noticias encontradas sobre su figura.

A continuación se reseñan colaboradores con una única participación en el Semanario y acerca de los cuales no hemos localizado información biográfica. Este es el caso de J. Albaceto (s.f.), contándose solo con la entrada catalogada en su momento. La firma de Emilio Bravo (s.f.), por el contenido del artículo recuperado a propósito del Liceo, no nos atrevemos a identificarla con la del jurista sevillano homónimo (1827-1893) que sí pudiera corresponderse por fechas de su biografía. A Rafael de Carvajal (s.f.) solo lo hemos encontrado citado como biógrafo del poeta Arolas, de acuerdo con la colaboración en el Semanario aquí recuperada. De Lluis Macià (s.f.), aunque no hemos hallado

65 Pere Virgili i Bellver (1699-1776), natural de Villalonga del Camp de Tarragona, cirujano militar en hospitales tarraconenses y valencianos, y fundador del Colegio de Cirugía y del Jardín Botánico de Cádiz. 
ningún dato biográfico, cabe destacar la llamada de atención de que, por fecha, su aportación es inmediata anterior a la demarcación del paraje de las salinas de Cardona en 1853, paraje sobre el que versa su artículo. Y tampoco localizamos noticia alguna de M. Parera (s.f.). Sin ninguna indicación existente acerca de su biografía, Julián Sáiz Milanés (s.f.) se documenta como periodista tan solo por seis colaboraciones en el Semanario sobre historia antigua, historia inca y arquitectura y arte, así como por su texto a propósito de historia medieval de la Corona de Aragón.

Además del más conocido pseudónimo, El Curioso Parlante, contamos con otro ya identificado en las páginas anteriores, El tío Fidel o Francisco Robello y Vasconi (datado desde 1848, fecha del inicio de su exilio en Ibiza). Es autor del artículo sobre la isla y asimismo de poesía y piezas teatrales de trasfondo político de corte liberal, ideología que motivó el citado exilio. Respecto de las siglas V. de la F., ya antes lo identificábamos con el aragonés Vicente de la Fuente y Condón (1817-1889), jurisconsulto, canonista e historiador con formación filológica y teológica (Ning 2008); así como y de acuerdo con A. Hernández Sánchez (2012: 1), R. de T. se identifica con el manchego Mariano Roca de Tagores (18121889), aristócrata y con responsabilidades políticas en el Partido Liberal, y que en su actividad académica y en su obra literaria y periodística siguió las pautas de la escuela romántica en la vertiente más tradicional (Amores 2008). Junto a estos dos últimos casos hay una serie de siglas sin identificar por nuestra parte, como es el caso de A., A. C., L. V., M. M. F., P. de M., S. H. y V. C. con una colaboración, R. y T. M. y R con dos, y N. B. S. con tres. También hay que notificar la existencia de abundantes colaboraciones anónimas, hasta un número de 86, cifra comparativamente superior a las encontradas en nuestras revisiones sobre las referencias portuguesas y gallegas en el Semanario Pintoresco Español. Por último, y dado que en no pocas ocasiones no se reconoce su firma y que en el caso en que lo hemos podido hacer no hemos hallado relevantes datos biográficos sobre los artistas (Benedicto o Puig, por ejemplo), no añadimos ninguna información. No por ello, en los apartados temáticos anteriores y en sus respectivas notas a pie de página, hemos dejado de incluir las correspondientes referencias bibliográficas a los grabados que aparecen aislados y sin encabezar ningún texto.

\section{BIBLIOGRAFÍA}

Amores, M. (2008) «Mariano Roca de Togores, Marqués de Molins», CIGES $X I X$. Versión electrónica http://gicesxix.uab.es/showAutor.php?idA=271 (consulta 15/03/2015).

- (2014) «El buscador de gices xix, herramienta digital sobre el cuento español del siglo XIX», Humanidades Digitales: desafíos, logros y perspectivas de futuro. Janus, Anexo 1, pp. 79-85.

Arroyo Almaraz, A. (ed.) (2012) Literatura y prensa romántica: El Artista y el Semanario Pintoresco Español en sus aniversarios, Madrid, CSIC. Número especial de Arbor, vol. 188, n. ${ }^{\circ} 757$. 
Bou, E. (dir.) (2000) Nou diccionari 62 de la literatura catalana, Barcelona, Edicions 62.

Burguera, M. (2011) «Historia e identidad: los lenguajes sociales del feminismo romántico en España (1844-1846)», Arenal, 18,1, enero-junio, pp. 53-83.

Canto, A. M. ${ }^{a}$ (2001) «Ivo de la Cortina y su obra Antigüedades de Itálica (1840): Una revista arqueológica malograda», CuPAUAM, 27, pp. 153161. Versión electrónica https://www.uam.es/otros/cupauam/pdf/Cupauam27/2708.pdf (consulta 15/4/2015).

Fuentes, J. F. + Fernández Sebastián, J. (1998) Historia del periodismo español, Madrid, Editorial Síntesis.

Hernández Sánchez, A. (2012) «El País Vasco en las revistas ilustradas españolas del siglo XIX y principios del XX», www.fsancho.sabio.es/html/SEMANARIO\%20PINTORESCO\%20ESPAÑOL.html (consulta 22.10.2014).

Lledó Patiño, M. (2012) «La visibilidad de las escritoras del S. XIX en el espacio público de la prensa», Estudios sobre el mensaje periodístico, 18, núm. especial nov., pp. 569-575.

Navas Sánchez-Élez, M. ${ }^{a}$ V. + Ribera Llopis, J. M. (2014) «Semanario Pintoresco Español (1836-1857): noticias sobre la cultura portuguesa», en Á. Marcos de Dios (ed.), La lengua portuguesa. Vol. 1. Estudios sobre literatura y cultura de expresión portuguesa, Salamanca, Ediciones Universidad de Salamanca, pp. 811-822.

- (2015) «Semanario Pintoresco Español (1836-1857): Noticias sobre cultura gallega en la prensa romántica centropeninsular», Madrygal, 18, pp. 481-493.

Ning, S. (2008) «Vicente de la Fuente», CIGES XIX. Versión electrónica http:// gicesxix.uab.es/show1 Autor.php?idA=272 (consulta 14/02/2015).

Prieto Prieto, V. (2014) «El profesor Antonio de Aquino e Izardo (1829-1906)», Alminar. Revista del Profesorado, 8, pp. 22-45.

Rubio Cremades, E. (1998) «El Semanario Pintoresco Español: el artículo de costumbres y géneros afines», en D. Flitter (coord.), Actas del XII Congreso de la Asociación Internacional de Hispanistas, Birmingham, 21-26 de agosto de 1995, The University of Birmingham-Doelphin Books, volumen 4, pp. 248-253.

Sánchez Aranda, J. J. + Herrera, C. (1992) Historia del periodismo español. Desde sus orígenes hasta 1975, Pamplona, Ediciones Universidad de Navarra.

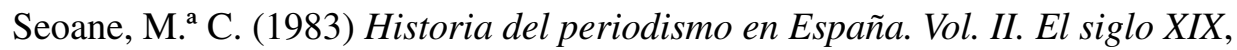
Madrid, Alianza Editorial.

Simón Díaz, J. (1946) Semanario Pintoresco Español (Madrid 1836-1857), Madrid, CSIC. 
